О.О. КИЛИМЕНЧУК, канд. техн. наук, доцент кафедри біохімії, мікробіології та фізіології харчування,

Г.Й. ЄВДОКИМОВА, канд. техн. наук, доцент кафедри біохімії, мікробіології та фізіології харчування,

О.В. ЩУР, студент, О.К. ШУЛЬГА, студент

Одеська наиіональна академія харчових технологій, м.Одеса

\title{
ВПЛИВ МАСЛА АМАРАНТУ НА КОРИСНУ МІКРОФЛОРУ ЛЮДИНИ
}

В статті наведено результати впливу масла амаранту та харчових волокон на ріст лактобацил in Vitro. Встановлено оптимальні співвідночення масла амаранту та харчових волокон, які позитивно впливають на корисну мікрофлору організму людини. Як тест-культуру було обрано Lactobacillus plantarum - одну із основних симбіотичних молочнокислих бактерій кишківника дорослої людини. Засівну культуру вносили у поживне середовище, яке імітувало умови илунково-кишкового тракту людини. Після термостатування протягом певного часу з усіх досліджуваних пробірок з маслом амаранту та харчовими волокнами і контрольних, відбирали по одному міллілітру і робили ряд десятикратних розведень. 3 останніх розведень усіх зразків проби вносили під капустяний агар. Після дводобового культивування підраховували кількість утворених, характерних для лактобачил колоній. Вивчали морфологічні та деякі біохімічні ознаки, в результаті чого було доказано, щчо вирощені лактобацили перебували у стані тургору, не модифікували, мали характерні для L.plantarum ознаки. Встановлено, шо лактобаиили у досліджуваних зразках $з$ маслом амаранту та харчовими волокнами значно прискорювали свій ріст порівняно із зразками, де були тільки харчові волокна. Приріст клітин під впливом масла амаранту досягав від 60 до 83 відсотків.

В результаті проведених досліджень встановлено, чо масло амаранту, як і харчові волокна впливає на колонізацію L.plantarum у кишківнику людини, а визначені оптимальні співвідношення масла амаранту і харчових волокон дають максимальний приріст необхідних організму лактобаиил.

Ключові слова: масло амаранту, лактобачили, харчові волокна, екологічна ніша, приріст біомаси.

Амарант - висока трав'яниста рослина 3 сімейства амарантових (Amarantaceae), яка походить 3 Центральної Америки, де з незапам'ятних часів була однією з основних харчових культур індіанців Нового Світу. Відома була ця рослина і в Греції. Амарант з грецької «амарантос» означає нев'янучий, оскільки у висушеному стані протягом багатьох місяців зберігає свою форму. Всього в світі відомі 65 родів та біля 900 видів амаранту. В Росії вирощують до 17 видів амаранту, серед яких найбільш розповсюдженими $€$ амарант запрокинутий або щириця звичайна, амарант мітлистий або багряний, амарант темний, трьохкомірний, хвостатий. В Україні амарант вирощують у дрібних фермерських господарствах.

До складу цієї рослини входить багато речовин, корисних для здоров'я: клітковина - $14 \%$, протеїн - $18 \%$, полісахариди - $18 \%$ та харчові волокна. Вчені доводять, що білок амаранту більш якісний, ніж білок молока, в ньому порівняно з іншими рослинними білками найбільше лізину. Рослина багата на калій, залізо, кальцій, магній і фосфор.

Насіння амаранту багато років тому, під час голоду на Україні, рятувало життя людям, які готували 3 нього їжу. Спеціально амарант не вирощували, вважали бур'яном, стебла та листя якого використовували як зелений корм для відгодівлі свиней у приватних господарствах.

3 насіння, останнім часом, почали отримувати масло, яке широко застосовується в фармакології, медицині, косметології.

До складу масла амаранту входить сквален $7,5 \%$, токотрієнол (особлива фракція вітаміну Е) $1,1 \%$; поліненасичені жирні кислоти (ПНЖК), фосфоліпіди - більше $9 \%$, фітостероли, каратиноїди, флавоноїди, макро- і мікроелементи. Вміст у маслі амаранту линолевої (омега-6) і олеїнової (омега-9) кислот досягає відповідно 28 і 40 \% від загальної кількості ліпідів.

Сквален - ациклічний поліненасичений вуглеводень $\mathrm{C}_{30} \mathrm{H}_{50} \epsilon$ важливим проміжним продуктом біосинтезу тритерпенів, зокрема ланостерину й стероїдних сполук у т.ч. холестерину, стероїдних гормонів та жовчних кислот.

За складом ПНЖК масло амаранту виключно унікальне, займає особливе місце серед органічних рослинних масел та містить збалансований комплекс омега-3 та омега-6, ПНЖК - так званий комплекс «вітаміну F» (від англ. Fat - жир).

ПНЖК мають гіполіпідемічні, гіпокоагуляційні, антиагрегатні властивості, протизапальний та імуномоделюючий ефекти.

Амарантове масло одне з небагатьох рослинних масел, яке містить тімнодонову (ліноленову, омега-3) ПНЖК (до 7 \% від усіх ПНЖК), альтернативним джерелом якої $є$ морепродукти - лососевий та скумбрієвий жири. Але вміст тімнодонової кислоти в цих морепродуктах набагато нижчий. Можливість метаболічного перетворення тімнодонової ПНЖК в простациклін без наступного перетворення в тромбоксан забезпечує антитромбогенну дію та дезагрегаційну дію і тому попереджує розвиток тромбозу та прогресування атеросклерозу.

Сквален вперше було виявлено у 1906 році і виділено 3 печінки глибоководної акули (від лат. Sgualus - акула). Для стабільності цьому природному ненасиченому вуглеводню не вистачає 12-ти атомів водню для стабільного стану, тому він захоплює ці атоми з будь-якого доступного джерела. А оскільки в організмі найбільш розповсюдженим джерелом водню $\epsilon$ вода, то сквален легко вступає 3 нею у взаємодію, вивільняючи кисень, і насичує ним органи і тканини. Глибоководним акулам сквален необхідний, 
щоб виживати в умовах надмірної гіпоксії (низький вміст кисню) при плаванні на великих глибинах. Люмікробна і фунгіцидна речовина, так як давно доказано, що саме дифіцит кисню і кисневе голодування клітин $є$ головними причинами старіння організму, а також виникнення пухлин. Потрапляючи в організм людини сквален омолоджує клітини, а також стримує виникнення і ріст злоякісних новоутворень, підвищує імунітет і опірність організму до різних захворювань. лось, що сквален $є$ похідним вітаміну А і при синтезі холестерину перетворює його в біохімічний аналог 7дегідрохолестерин, який при сонячному світлі перетворюється в вітамін Д, забезпечуючи радіопротекторні властивості. Вітамін А краще всмоктується, коли він розчинений у сквалені.

Унікальний хімічний склад масла амаранту дозволяє його застосовувати при лікуванні запалювальних процесів, виразки шлунка і дванадцятипалої кишки, сечостатевої системи, анемії, цукрового діабету, ожиріння, неврозів, захворювань шкіри, стоматиту, атеросклерозу та багатьох інших.

Оскільки у маслі амаранту велика кількість активно діючих речовин, які позитивно впливають на макроорганізм, слід було б визначити, чи мають ці речовини такий же вплив на мікроорганізми тонкого кишківника (молочнокислі), чи не пригнічують їх ріст та розмноження? Лактобацили, які переважають серед молочнокислих мікроорганізмів дорослої людини, досить вимогливі до складу поживного середовища і потребують внесення в них амінокислот, вітамінів, жирних кислот, вуглеводів і похідних нуклеїнових кислот (індивідуальні для кожного виду). Всередині кишківника вони зброджують лактозу до молочної кислоти, яка надає антисептичну дію і трансформує кальцій, що надходить з їжею, в засвоюваний вчення впливу масла амаранту на внутрішню мікрофлору кишківника людини, а саме - на позитивну молочнокислі бактерії. В літературі дані про це відсутні. ступне:

Для досягнення цієї мети було проведено на-

- зроблено огляд літератури;

- розроблено схему дослідження in Vitro процесу травлення їжі у присутності масла амаранту та розрахунок розхідних матеріалів;

- підібрано культуру молочнокислих бактерій;

- проведено експериментальні дослідження та облік результатів;

- зроблено висновок про вплив діючих компонентів масла амаранту на мікрофлору кишківника. дині сквален необхідний як антиканцерогенна, анти-

Під час біохімічних досліджень сквалена було виявлено багато інших його властивостей. Виявилактат кальцію. Тому метою даної роботи стало ви-

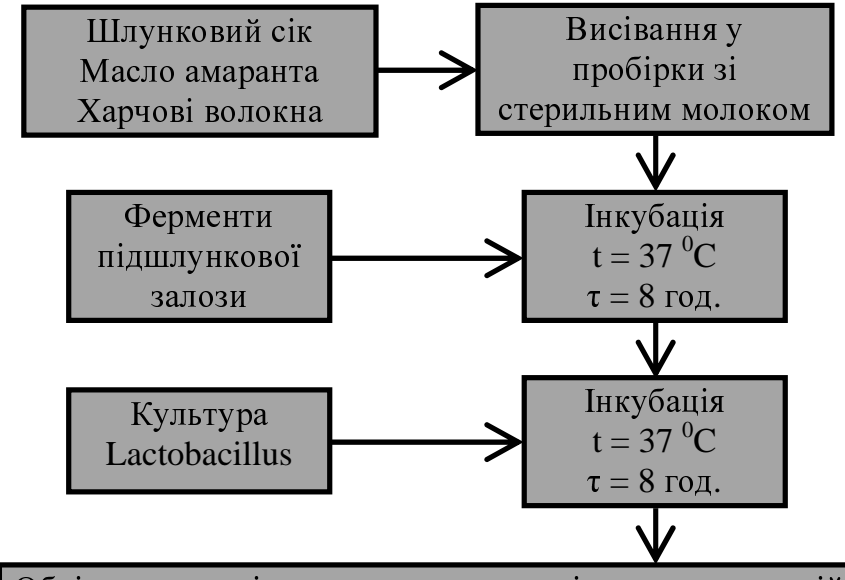

Облік результатів методом прямого підрахунку колоній

\section{Рис. 1 - Схема проведення експериментальних досліджень щцодо впливу масла амаранту на Lactobacillus plantarum}

На рис. 1 наведено схему проведення досліджень. Хід дослідження

В підготовлені пробірки зі стерильним молоком (жирністю 1,5 \%) вносили шлунковий сік, масло амаранту виробника ООО «Торговый дом - Таврийские млынари», харчові волокна у вагових та об'ємних одиницях. Розрахунок інгредієнтів було зроблено для людини середньої статури віком до 30 років, виходячи з рекомендацій теорії раціонального харчування. Харчових волокон було внесено 0,01, 0,03, 0,05 г у межах максимальної добової потреби людини (25 г на добу). Контролем слугували пробірки $з$ харчовими волокнами без додавання масла амаранту і молоко без масла і харчових волокон, інкубовані у аналогічних умовах з такою ж кількістю шлункового соку та ферментів.

Після двогодинного термостатування додавали тонко подрібнений ферментний препарат та знову витримували у термостаті протягом 6 годин.

Після термостатування у суміш інгредієнтів, яка імітувала химус людського організму, засівали культуру Lactobacillus plantarum i продовжили культивування $\left(\mathrm{t}=37^{\circ} \mathrm{C}\right)$ ще 8 годин.

Ефективність росту культури на створених поживних середовищах у присутності масла амаранту досліджували методом 10-кратних розведень. По 1 мл з останніх розведень кожного зразка засівали у чашки Петрі і викладали у термостат на 2 доби при $\mathrm{t}=30^{\circ} \mathrm{C}$. Як поживне середовище для ідентифікації L.plantarum застосували капустяний агар.

Облік посівів робили прямим підрахунком колоній з розведень $10^{5}, 10^{6}, 10^{7}$.

Результати наведено у табл. 1.

Як тест-культуру для дослідження було обрано Lactobacillus plantarum, оскільки вона є однією з ос-

Таблиця 1

Облік колоній молочнокислих бактерій Lactobacillus plantarum

\begin{tabular}{|c|c|c|c|c|}
\hline $\begin{array}{c}\text { №№ } \\
\text { 3/ח } \\
\end{array}$ & $\begin{array}{c}\text { Харчові волокна, } \\
\Gamma \\
\end{array}$ & $\begin{array}{c}\text { Масло амаранту, } \\
\text { мл } \\
\end{array}$ & КУО/мЛ & $\begin{array}{c}\text { КУО/мл } \\
\text { контроль (без масла) }\end{array}$ \\
\hline 1. & $\begin{array}{l}0,01 \\
\end{array}$ & 0,3 & $15 \cdot 10^{8}$ & $48 \cdot 10^{7}$ \\
\hline 2. & 0,03 & 0,3 & $15 \cdot 10^{8}$ & $32 \cdot 10^{7}$ \\
\hline 3. & 0,05 & 0,3 & $24 \cdot 10^{8}$ & $5 \cdot 10^{8}$ \\
\hline
\end{tabular}
новних симбіотичних молочнокислих бактерій кишківника дорослої людини. Засівну чисту культуру надано з музею культур кафедри біохімії, мікробіології та фізіології харчування ОНАХТ. 


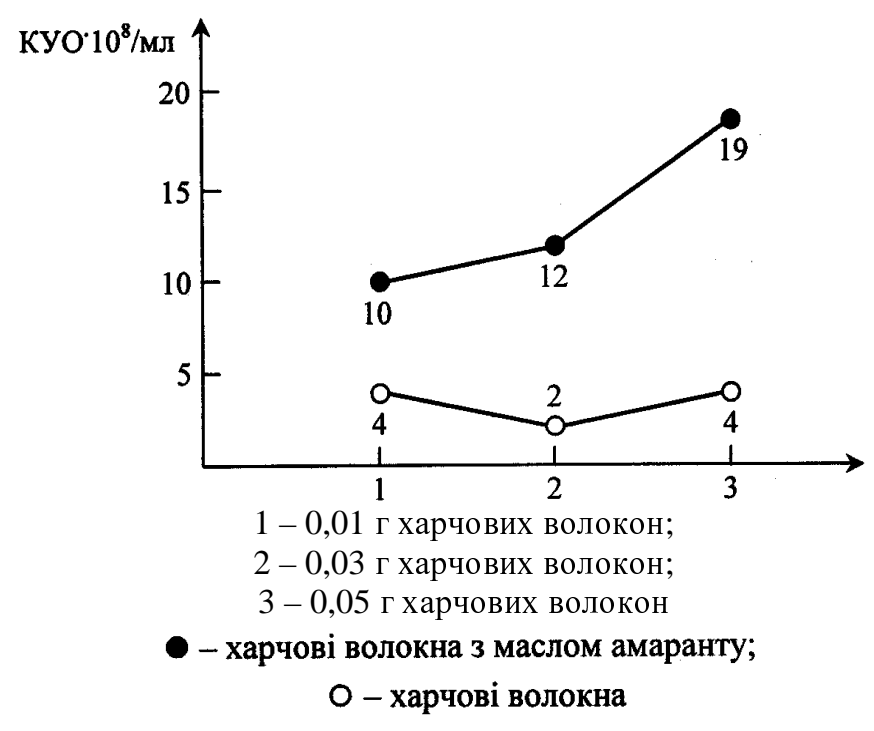

Рис. 2. Вилив масла амаранту та харчових волокон на L.plantarum

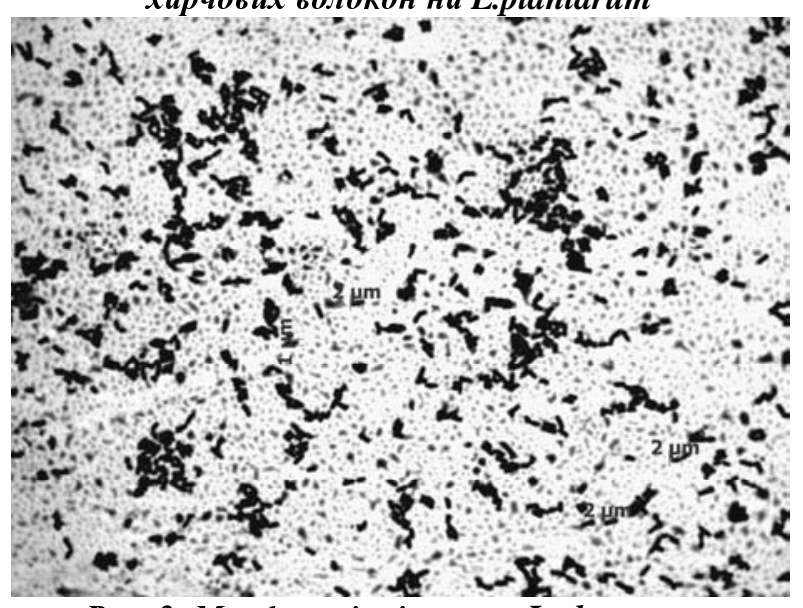

Pис. 3. Морфологічні ознаки L.plantarum, культивованих з маслом амаранту та харчовими волокнами

Приріст кількості клітин L.plantarum за рахунок сумісного впливу харчових волокон і масла амаранту та окремо харчових волокон показано на рис.2.

Наведений на рис. 2 графік свідчить, що приріст клітин L.plantarum за рахунок впливу масла амаранту у третьому зразку складає $79 \%$, а у зразках 1,2
- $60 \%$ та $83 \%$ відповідно. Приріст клітин було розраховано відносно контролю, у якому було тільки стерильне молоко та відповідні ферменти без додавання масла амаранту та харчових волокон.

Аналіз проведених досліджень свідчить, що масло амаранту, як і харчові волокна впливають на колонізацію L.plantarum у кишківнику людини. Найвищий ріст $24 \cdot 10^{8}$ клітин виявлено у зразку з маслом амаранту, де вміст волокон 0,05 г. При інкубації вмісту пробірок у термостаті спостерігалось активне газоутворення, особливо у тих пробірках, де були харчові волокна і масло.

На капустяному агарі спостерігали ріст характерних дрібних сіруватих колоній. Видову приналежність підтвердили морфологічно, деякими біохімічними ознаками та здатністю рости на капустяному агарі при $\mathrm{t}=30{ }^{0} \mathrm{C}$. Лактобацили не змінили свій вигляд, не модифікували, перебували у стані тургору та мали розміри $2 \times 1$ мкм (рис. 3 ).

Це пояснюється тим, що компоненти масла амаранту у поєднанні з оптимальною кількістю харчових волокон $(0,05$ г) створюють пробіотичний комплекс, основу якого складають синергічно діючі компоненти - молочна кислота, амінокислоти, вітаміни, $\mathrm{H}_{2} \mathrm{O}_{2}$, антибіотичні субстанції. Слід зазначити, що унікальною характеристикою L.plantarum $\epsilon$ здатність катаболізувати аргінін з утворенням окису азо ту. Ця речовина приймає участь в серії найважливіших функцій шлунково-кишкового тракту (бактеріостатична дія у відношенні кандіда, кишкових паличок, шигел, сальмонели, хелікобактерій, амеб, кишкових паразитів; секреції муцина; регуляції перистальтики; стимуляції імунних функцій, пов'язаних 3 травною системою; попередження всмоктування ендотоксинів у сироватку крові).

Висновок.Встановлені нами оптимальні співвідношення масла амаранту (0,3 мл) та харчових волокон $(0,05$ г) створюють комфортну ендоекологічну нішу для вибагливих L.plantarum. При цьому харчові волокна структурують внутрішнє середовище, рівномірно розподіляючи трансформовані у шлунково-кишковому тракті активні компоненти масла амаранту і стимулюють ріст необхідних організму лактобацил.

\section{СПИСОК ЛІТЕРАТУРИ}

1. Шендеров В. А. Медииинская микробная экология и функииональное питание / В. А. Шендеров // Том ІІІ: Пробиотики и функииональное питание. - М.: Изд-во «ГРАНТЪ», 2001. - 288 c.

2. Bengmark S. Ecoimmunonutrition: A Chalenge for the Third Millenium / S. Bengmark // Nutrition, 1998, V. 14. - № 7/8. - P. 563-572.

3. Чиркова Т. В. Амарант - культура ХХІ века / Т. В. Чиркова // СОЖ, 1999, № 10. - С. 22-27.

4. Железняков А. В. Хлеб, зрелище и лекарство / А. В. Железняков // Химия и жсизнь. - 2005. - № 6. - С. 56-61.

5. Сгорова А. В. Насіння амаранту можна уберегти від згубної дї̈ мікрофлори / А. В. Єгорова, Г. Й. Євдокимова, Л. К. Овсянникова та ін. // Зерно і хліб. - 2008. - № 1. - С. 34-35.

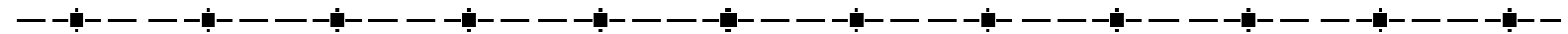

O.O. KILIMENCHUK, PhD. Sc. Science, Associate Professor, G.Y. EVDOKIMOVA, PhD. Sc. Science, Associate Professor, O.V.SHUR, O.K. SHULGA

\section{Odessa National Academy of Food Technologies, Odessa}

\section{INFLUENCE AMARANTH OIL INTO USEFUL MICROFLORA OF HUMANS}

Results of influence of amaranth oil and dietary fibers on Lactobacillus growth in Vitro are showed in the article. Was defined the optimum ratio of amaranth oil and fibers, which positively influence the microflora of the human body. As the testculture was chosen Lactobacillus plantarum - one of the basic symbiotic lactic bacteria of the adult person intestine. The inoculum was applied into a nutrient medium which simulated conditions of a gastroenteric path of the person. After thermostating for a certain time from all test tubes with oil and amaranth fiber were selected by one milliliter and series of tenfold dilutions was made. Last samples of dilutions were added under a cabbage agar. After two-daily cultivation quantity 
of specific colonies for Lactobacillus were counted up. Morphological and some biochemical characters were studied, whereby it was proved that grown lactobacilli in a state of turgor were not modified, L.plantarum had typical L.plantarum symptoms. It was found that, Lactobacillus in researched samples with amaranth oil and food fibres considerably accelerated the growth in comparison with samples where there were only dietary fibers. Growth of cells under the influence of amaranth oil reached 60 to 83 percent.

The studies found that amaranth oil as dietary fibers affects on L.plantarum colonization in the human intestine, define optimal correlation of amaranth oil and fiber gives maximum growth of necessary lactobacilli for an organism.

Keywords: amaranth oil, lactobacilli, dietary fibers, ecological niche, biomass increase.

\title{
REFERENCES
}

1. Shenderov B.A. Medical microbial ecology and functional nutrition / B. A. Shenderov // Part III: Probiotics and functional nutrition. Moscow : Publishing house «GRANT», 2001. - 288 p.

2. Bengmark S. Ecoimmunonutrition: A Chalenge for the Third Millenium / S. Bengmark // Nutrition, 1998, V. 14. - № 7/8. - P. $563-572$.

3. Chirkova T. V. Amarant - the culture of the XXI century / T. V. Chirkova // LCL, 1999, № 10. - P. 22-27.

4. Zheleznyakov A. V. The bread, the show and the medicine / A. V. Zheleznyakov // Chemistry and life. - 2005. - № 6. - P. 56-61.

5. Yegorova A. V. Amaranth's seeds can be saved from fatal action of microflora / A. V. Yegorova, G. Y. Yevdokymova, L. K. Ovsyannykova and other // Grain and bread. - 2008. - № 1. - P. 34-35.

\section{Поступила 20.06.2014 Адреса для переписки: вул. Канатна, 112, м. Одеса, 65039}

М.Р. МАРДАР, Д-р. техн. наук, доцент, Г.В. КРУСИР, д-р. техн. наук, професор, А.І. ЯНІВСЬКА, магістр, І.П. КОНДРАТЕНКО, ст. вИКЛадач, О.В. МАЛЕЦЬКА, асПіранТ, Одеська національна академія харчових технологій, м. Одеса

\section{БIОТЕСТУВАННЯ В ОЦІНЮВАННI БЕЗПЕЧНОСТI ЗЕРНОВИХ ПЛАСТІВЦІВ}

\begin{abstract}
Стаття присвячена питанню безпечності харчових продуктів як важсливого показника спожсивних властивостей та визначального критерію їх якості.

Очінено безпечність пшеничних пластівців, які реалізуються на ринку, у торговельній мережі м. Одеси, а також нового виду пластівців на основі нетрадиційної сировини, а саме, чорнозерної пшениці за допомогою методів біотестування. Біотестування використовується для визначення ступеня пошкоджуючого впливу хімічних речовин, потенційно небезпечних для живих організмів иляхом реєстрації змін біологічно значимих показників дослідних тест-об'єктів с наступною оиінкою ӥх стану у відповідності з обраним критерієм токсичності. При проведенні досліджень зернових пластівиів застосовували методи з тест-організмами із різних систематичних груп. Першим методом визначали токсичності пшеничних пластівців за допомогою тест - об'єкта інфузорії Colpoda steinii, на основі другого метода проводили тестуванні по загибелі ракоподібних Daphnia Magna Straus, третій метод проводили за методикою, заснованою на пророщуванні корінців цибулі звичайної Alliuт сера.

За результатами біотестування встановлено, щьо нові види пластівців із чорнозерної пшениці, а також пластівці відомих торгових марок є нетоксичними, на відмінну від зразка пшеничних пластівців, який був придбаний на ринку м. Одеси. Проведені дослідження дозволило оиінити безпечність продукиії, яка розробляється для населення, можливість порівняння ї̈ із зерновими пластівиями, які існують на ринку, а також в майбутньому буде розглянуто перспективу виведення на ринок нових видів пластівців із чорнозерної пиениці як безпечного продукту.
\end{abstract}

Ключові слова: біотестування, зернові пластівиі, безпечність продукту, токсичність.

Безпечність - це важливий показник споживних властивостей, яким повинні володіти продукти харчування. На відміну від інших споживних властивостей, погіршення або втрата яких веде до втрат функціонального або соціального призначення, підвищення допустимого рівня показників безпечності переводить продукцію до категорії небезпечної. Тому якість харчових продуктів у першу чергу визначається безпечністю. Згідно Закону України «Про якість та безпеку харчових продуктів і продовольчої сировини» [1] безпечний харчовий продукт - це харчовий продукт, який не створює шкідливого впливу на здоров'я людини безпосередньо чи опосередковано за умов його виробництва та обігу з дотриманням вимог санітарних заходів та споживання (використання) за призначенням.
У теперішній час на ринку продуктів харчування України все більшою популярністю серед споживачів користуються зернові пластівці. Для оцінки відношення споживачів до даного харчового продукту першочергово було проведено маркетингове дослідження споживчих переваг та мотивацій при виборі зернових пластівців [2], в ході якого респондентам були задані питання, що стосуються асортименту зернових пластівців, представленого у торговельній мережі м. Одеси. Розподіл респондентів здійснено за рівнем освіти, родом занять, віком та статтю. У результаті виявлено, що більшість респондентів вважають, що асортимент традиційних зернових пластівців представлено у торговельній мережі досить обмежено (52 \%); задоволені асортиментом $29 \%$ респондентів; вагалися з відповіддю $19 \%$. На запитання 